\title{
TaYS1A, a Yellow Stripe-Like Transporter Gene, Is Required for Wheat Resistance to Puccinia striiformis f. sp. Tritici
}

\author{
Md Ashraful Islam ${ }^{+} \mathbb{D}$, Jia Guo ${ }^{\dagger}$, Huan Peng, Shuxin Tian, Xingxuan Bai, Haochuan Zhu, \\ Zhensheng Kang * $\mathbb{D}$ and Jun Guo
}

State Key Laboratory of Crop Stress Biology for Arid Areas, College of Plant Protection, Northwest A and F University, Yangling 712100, China; a.islam160@nwafu.edu.cn (M.A.I.); guojia1889@nwafu.edu.cn (J.G.); penghuan@nwafu.edu.cn (H.P.); tianshuxin@nwafu.edu.cn (S.T.); baixingxuan@nwafu.edu.cn (X.B.); zhuhaochuan@nwafu.edu.cn (H.Z.); guojunwgq@nwsuaf.edu.cn (J.G.)

* Correspondence: kangzs@nwsuaf.edu.cn; Tel./Fax: +86-29-87080061

† These authors contributed equally to this work.

Received: 22 October 2020; Accepted: 27 November 2020; Published: 3 December 2020

\begin{abstract}
Yellow stripe-like (YSL) transporters are required for the transportation of metalphytosiderophores and are structurally related to metal-nicotianamine complexes. Some studies also reported the involvement of YSL transporters in pathogen-induced defense. However, the molecular mechanisms of YSL genes involved in biotic stress responses are still not clear, especially in cereal crops. This study aimed to functionally characterize TaYS1A during the interaction of wheat and Puccinia striiformis f. sp. tritici (Pst), the causal agent of stripe rust disease. TaYS1A was localized in the cell membrane of wheat protoplasts and Nicotiana benthamiana cells. TaYS1A was significantly up-regulated in wheat leaves after being infected with the avirulent Pst isolate CYR23 and after treatment with salicylic acid (SA). Silencing of TaYS1A by the virus-induced gene silencing method enhanced the susceptibility of wheat to Pst accompanied by reducing the accumulation of SA and $\mathrm{H}_{2} \mathrm{O}_{2}$ and down-regulating the transcriptions of TaPR1 and TaPR2. In addition, TaYS1A was found to interact with TaNH2, a homolog of OsNH2, by yeast-two-hybrid assay, and silencing of TaYS1A diminished the expression of $\mathrm{TaNH} 2$. Our findings suggested the existence of positive regulation of TaYS1A in providing resistance against $P$ st by modulating SA-induced signaling and offered new insight into the biological role of YSL in wheat against pathogens.
\end{abstract}

Keywords: wheat; yellow stripe-like transporter; salicylic acid; Puccinia striiformis f. sp. tritici; resistance; VIGS

\section{Introduction}

Pst, causing wheat stripe rust, is a major challenge to global wheat production. One of the most economical and productive strategies for stripe rust management is to develop resistant wheat cultivars. Dissection of the molecular interaction pathways between wheat and Pst would promote the appropriate use of resistance genes for varietal improvement. Usually, plants produce a sequence of immune responses to defend against pathogen invasion, such as ion fluxes through the plasma membrane, increased intracellular $\mathrm{Ca}^{2+}$ concentration, accumulation of reactive oxygen species (ROS), biosynthesis of salicylic acid (SA), fortification of the cell-wall, a hypersensitive response (HR), the formation of localized cell wall appositions (CWAs or papillae), among others [1-4]. Among those, CWAs is one of the common innate or basal defense response against pathogens infection by a burst of ROS and pathogenesis-related (PR) protein production. Beyond the establishment of CWAs, ROS are also involved in several plant signaling regulations including local and systemic signaling essential for 
plant immunity [4-6]. Salicylic acid (SA) also was shown to be a crucial regulator of multiple stages of immunity among these signaling systems, protecting plants from a broad variety of microorganisms by mitigating local and systemic immune responses. SA signaling through NPR1 (non-expresser of pathogenesis-related protein 1) is essential for the development of systemic acquired resistance (SAR) [7,8]. In rice, over-expression of NH1/NH3 (NPR1 homologs) exhibited increased resistance to Magnaporthe oryzae and Xoo, suggesting its positive roles in host resistance against pathogens $[9,10]$. Liu, et al. [11] reported that an OsNH2 homolog TaNH2, was induced by Pst infection and SA treatment and was required for wheat resistance to Pst. However, research on the functions of NPR1 homologous genes in wheat is still quite limited.

Iron $(\mathrm{Fe})$ is one of the most important micronutrients required for different physiological processes of plants, e.g., respiration, chlorophyll biosynthesis, photosynthesis, and nitrogen assimilation [12,13]. In addition to involvement in physiological processes, Fe is readily involved in one electron reduction-oxidation (redox) reactions to catalyze the formation of ROS through the Fenton reaction $[14,15]$. Maize in Fe-deficient condition was unable to produce ROS at the site of Colletotrichum infection, which increased susceptibility to this fungus [16]. In turn, ROS production, especially resistance-linked hydrogen peroxide $\left(\mathrm{H}_{2} \mathrm{O}_{2}\right)$, is dependent on the accumulation of redox-active ferric iron ions $\left(\mathrm{Fe}^{3+}\right)$ in cereal crops [16-18]. Reactive $\mathrm{Fe}^{3+}$ accumulated at cell wall appositions to induce oxidative burst and intracellular depletion of Fe provoked by pathogen infection; this condition led to the induction of pathogenesis-related genes along with $\mathrm{H}_{2} \mathrm{O}_{2}$ [18]. Immediately after pathogen invasion, ROS accumulation begins, which has been linked with the generation of superoxide in apoplast to induce a signal for further immune response by Fe-containing transmembrane NADPH oxidases but that is impermeable to plant cell membrane. The generation of membrane-permeable $\mathrm{H}_{2} \mathrm{O}_{2}$ can take place from the conversion of superoxide by superoxide dismutases; in some of these Fe has a function as a cofactor [19-22]. Moreover, some recent studies in rice revealed an important function of $\mathrm{Fe}$ as a regulator of $\mathrm{HR}$ cell death during effector-triggered immunity (ETI) through a ferroptosis mechanism in response to avirulent race of rice blast pathogens [23,24]. In Arabidopsis, frd3 mutant disrupted the localization of Fe in the cell wall, triggering biotic stress response through ROS production [25]. Thus, complex regulatory mechanisms have been involved during plant-pathogens interactions that harmonize Fe acquisition and homeostasis. However, plant species possess two classes of strategies to acquire a sufficient amount of Fe from the soil in a regulated manner. Nongraminaceous plants used strategy I to decrease ferric chelates at the root surface and absorb ferrous ions across the root plasma membrane via iron transporters. In grasses, yellow stripe-like (YSL) transporters take up Fe-PS (phytosiderophores) complexes from the soil and translocate throughout the plant by strategy II [26-30].

YSLs belong to the oligopeptide transporter (OPT) family, one of the major groups of membrane-bound integral proteins that are involved in the transfer, detoxification, or remobilization of metals, relying on the nutrient levels in the plant and its position of action [31-33]. Long-distance transport in shoots/leaves is carried out via phloem, in which YSLs have also been reported to be involved in nutrient remobilization of storage tissue [34,35]. In addition to metal transportation, YSLs have been found to take part in the defense against pathogens. In Arabidopsis, YSL3 was found to be strongly expressed in the siz1 mutant, and the plant displayed elevated levels of SA and SA glucoside. Elevation of SA in siz1 plants triggered transcription of pathogenesis-related (PR) genes, improving resistance to pathogenic bacteria $[36,37]$. It was also reported that the transcription of AtYSL3 could be triggered by SA through an NPR1-dependent pathway, which positively regulates the basal resistance [38]. NPR1 in Arabidopsis, is a receptor of SA and is a transcriptional coregulator of SA-dependent defense-related gene activation [39,40]. NPR1 modulates the transcript of almost $99 \%$ of SA-responsive genes, indicating its importance in SA signaling pathways and transcriptional reprogramming during plant defense. As transcriptional coactivators, NPR1 monomers interact with TGA transcription factors, which bind the promoter of $P R$ genes, to activate the expression of $P R$ genes [41,42]. Thus, it is reasonable to assume that in presence of SA, NPR1 regulates the 
activation of YSLS and the metal homeostasis function of YSL genes may induce ROS mediated HR and defense-related genes to establish plant immunity during pathogen infection. Nevertheless, in wheat, some studies on YSLs have been carried out and the functions of YSLs in wheat defense against Pst are still unknown.

In the present investigation, we carried out TaYS1A gene isolation and characterized its roles during wheat-Pst interactions. We analyzed the transcript level of TaYS1A in Pst-inoculated wheat seedlings and hormone-treated plants and observed the subcellular localization of TaYS1A. We found that suppression of TaYS1A transcription enhances the susceptibility of wheat to Pst. Through yeast two hybrid assays and silencing of TaYS1A, we also found that TaYS1A interacted with TaNH2, an Arabidopsis NPR3/4 orthologue. Our results suggest that TaYS1A plays a positive role in SA-dependent wheat resistance to the stripe rust fungus.

\section{Materials and Methods}

\subsection{Plant Materials, Fungal Isolates and Treatments}

Chinese wheat cultivar, Suwon11(Su11), N. benthamiana, and Pst isolates CYR23 and CYR31 were used as the study materials. Wheat (Triticum aestivum L.) variety Suwon11 (AUS-22519) originated from the Seuseun Agricultural Experiment Station (Sariwon, Korea) was registered in the Australian Winter Cereal Collection, Tamworth, Australia. Su11 carrying a stripe rust resistance gene $Y r S u$, produces an incompatible interaction with CYR23 and compatible interaction with CYR31 [43]. Maintenance of wheat seedlings growth and inoculation was performed as previously done by Kang, et al. [44]. For RNA extraction first leaves of CYR23, CYR31, or sterile distilled water (mock control) inoculated wheat seedlings were collected at $0,6,12,18,24,36,48,72$, and 120 hpi. In the case of hormone treatments, wheat seedlings were sprayed with $10 \mathrm{mM}$ salicylic acid (SA), $100 \mathrm{mM}$ abscisic acid (ABA), $100 \mathrm{mM}$ methyljasmonate (MeJA), and $100 \mathrm{mM}$ ethepon (ETH). The solvent $0.1 \%$ $(v / v)$ ethanol was applied to treat mock control plants and then sampled at 0, 0.5, 1, 2, 12, 24 and $48 \mathrm{hpt}$ for RNA extraction. Tissue-specific expression analysis was performed on root, stem, and leaves of 12 days wheat seedlings. To preserve the plant samples for further RNA isolation, they were instantly frozen in liquid $\mathrm{N}_{2}$ followed by storage at $-80^{\circ} \mathrm{C}$. For every treatment, three independent biological replications were included.

\subsection{RNA Extraction and $q R T-P C R$}

For RNA extraction, the Quick RNA isolation Kit (Huayueyang Biotechnology, Beijing, China) was used following the manufacturer's protocols. DNA contamination was eliminated through DNase I treatment. A 3- $\mu$ g aliquot of the total RNA of each sample was used for cDNA synthesis with the RevertAid First Strand cDNA Synthesis Kit (Thermo Scientific, Waltham, MA, USA). TaYS1A expression analysis was conducted by qRT-PCR assay and presented as the TaYS1A transcript level in both virulent/avirulent $P$ st inoculated and chemical treated wheat leaves compared to mock control wheat leaves. Specific primers were designed for qRT-PCR analysis (Table S1), as suggested previously [45]. Threshold values (CT) were obtained with the ABI PRISM 7500 system (Applied Biosystems, Foster City, CA, USA). Then, using the comparative $2^{-\triangle \Delta C T}$ method [46], the transcription level of TaYS1A was quantified. The Elongation factor 1 (TaEF-1 $\alpha$ ) was used to normalize the data (GenBank accession no.Q03033) [47] (Table S1). All experiments were replicated three times.

\subsection{Sequence Analysis of TaYS1A}

TaYS1A was amplified from CYR23-inoculated Su11 cDNA template with specific primers (Table S1). Sequencing of TaYS1A was done by purifying the PCR DNA and inserted into the pGEM-T Easy vector (Promega, Madison, WI, USA). The copies of TaYS1A and other related sequences were obtained from the Ensemble Plant database. Blast programs in NCBI (https://www.ncbi.nlm.nih. gov/) were used for analyzing sequences. ORF Finder (https://www.ncbi.nlm.nih.gov/orffinder/), 
NCBI Nucleotide Blast, and the Protein Blast programs (https:/www.ncbi.nlm.nih.gov/) were used for the analyses of cDNA sequences.

\subsection{Subcellular Localization of TaYS1A Protein}

A pCaMV35S:TaYS1A-GFP fusion plasmid was generated for investigating the subcellular localization in wheat protoplasts. Wheat protoplasts were extracted from the mesophyll tissue of ten-day-old wheat seedlings as described [48]. The recombinant construct pCaMV35S:TaYS1A-GFP or pCaMV35S: GFP was transferred into wheat protoplasts by Polyethylene glycol (PEG)-calcium transfection [49]. For further confirmation of TaYS1A localization, we used Agrobacterium infiltration assay in N. benthamiana. Agrobacterium infiltration results in a large number of transformed cells within an intact tissue $N$. benthamiana that can easily be identified and analyzed at the subcellular level within a short period [50]. The recombinant pCAMBIA1302:TaYS1A-GFP fusion was constructed using AvrII and SpeI restriction sites and transformed into the $A$. tumefaciens strain GV3101 by electroporation. Infiltration of $N$. benthamiana leaves was done following the procedure described by Cheng, et al. [51]. Infiltrated plants were maintained for $2-3$ days at $25^{\circ} \mathrm{C}$ with a light cycle of $16 \mathrm{~h}$ light and $8 \mathrm{~h}$ dark and then tissue samples were collected to observe GFP autofluorescence. An Olympus FV1000 confocal laser microscope with a $488 \mathrm{~nm}$ filter was used to image GFP autofluorescence.

\subsection{BSMV-Mediated VIGS of TaYS1A}

Two specific cDNA fragments of TaYS1A (Figure S1) were designed and analyzed for VIGS. The fragments were obtained with NotI and PacI restriction sites by reverse transcription PCR and cloned into BSMV: $\gamma$ to modify the original barley stripe mosaic virus (BSMV), which is designated as BSMV:TaYS1A-1/2as [52]. No similarity in the fragments was found with any other wheat genes in the BLAST analyses (http://blast.ncbi.nlm.nih.gov/Blast/), indicating the specificity of the selected segments. Capped in vitro transcripts were obtained with the RiboMAX TM Large-Scale RNA Production System-T7 (Promega) and the Ribo $\mathrm{m}^{7} \mathrm{G}$ Cap Analog (Promega) following the manufacturer's protocol. The second leaves of two-leaf-stage wheat seedlings were mechanically rubbed with BSMV constructs and incubated for $24 \mathrm{~h}$ under dark and humid conditions. After incubation, the inoculated plants were transferred to a growth chamber maintained at $25 \pm 2{ }^{\circ} \mathrm{C}$ and a $16 \mathrm{~h}$ photoperiod. Mock plants were rubbed with $1 \times$ Fes. Ten days after virus inoculation, the fourth leaves of wheat were inoculated with freshly harvested Pst isolates CYR23 or CYR31 urediniospores. The inoculated leaves were sampled at 0 , 24, 48, and 120 hpi for RNA isolation and histological observations. The relative expression of TaYS1A, the expression level of two pathogenesis-related (PR) genes (TaPR1 and TaPR2), and ROS-related genes were analyzed by qRT-PCR assay. Wheat phenotypes after Pst inoculation were examined based on the McNeal measurements scale [53] and photographed at 14 dpi. Fungal biomass was analyzed by qRT-PCR. Genomic DNA was extracted using the CTAB method from samples collected at 14 dpi after infected with Pst and a standard curve was generated by the plasmid carried the fragment of PsEF1 and TaEF1 as previously described [54,55]. All experiments were conducted in triplicate and 50 plants were used for each fragment at each time.

\subsection{Histology of Host Response and Fungal Growth}

The samples of TaYS1A-silenced plants were stained for histological observation. For the detection of $\mathrm{H}_{2} \mathrm{O}_{2}$ accumulation, infected leaves were stained with $3,3^{\prime}$ - diaminobenzidine (DAB, Amresco, Solon, $\mathrm{OH}, \mathrm{USA}$ ) and then observed microscopically [56]. For visualizing pathogen structures, wheat germ agglutinin (WGA) conjugated to Alexa-488 (Invitrogen, Carlsbad, CA, USA), which specifically stains Pst, was used as described previously [57]. The site where an appressorium had formed over a stoma was considered to be a successful penetration site of Pst. The accumulation of $\mathrm{H}_{2} \mathrm{O}_{2}$, necrotic areas, hyphal length, haustoria mother cell, hyphal branches, and infection areas were observed under ultraviolet light with a microscope (Olympus Corporation, Tokyo, Japan), and the DP-BSW software (Olympus Corporation, Tokyo, Japan) was used to calculate length and area. A minimum of 50 infection 
sites were examined on each of five randomly selected leaf segments for each treatment. The experiment included three independent biological replications.

\subsection{SA Analysis}

For SA quantification, about $200 \mathrm{mg}$ of fresh leaves were ground in liquid $\mathrm{N}_{2}$ and extracted with $750 \mu \mathrm{L}$ of $\mathrm{MeOH}^{-}: \mathrm{H}_{2} \mathrm{O}^{-}: \mathrm{HOAc}(90: 9: 1, v / v / v)$. The analysis was done by HPLC-MS (API 2000; AB SCIEX, Framingham, MA, USA). All procedures and analyses were carried out with three biological replications according to the protocol used by Segarra, et al. [58].

\subsection{Yeast Two-Hybrid Assay}

The recombinant pGBKT7-TaYS1A vector was constructed by inserting the coding sequence of TaYS1A with primers TaYS1A-BD-F/R and the recombinant $\mathrm{pGADT7-TaNH2} \mathrm{vector} \mathrm{was} \mathrm{constructed} \mathrm{by}$ inserting the coding sequence of TaNH2 with primers TaNH2-AD-F/R (Table S1). For interaction assay, pGBKT7-TaYS1A and pGADT7-TaNH2 were co-transformed into the yeast strain AH109 by the lithium acetate method following the Yeast Protocols Handbook (Clontech) and plated on the SD/-Trp-Leu or $\mathrm{SD} /$-Trp-Leu-His selection medium. We selected colonies from SD/-Trp-Leu-His and plated them on SD/-Trp-Leu-His-Ade medium again for further selection. The interaction was confirmed by plating on SD/-Trp-Leu-His-Ade medium containing X- $\alpha$-gal. The combination of pGBKT7-TaCIPK10 and pGADT7-TaNH2 was used as a positive control [11] and the combination of pGBKT7-TaYS1A and pGADT7 empty vector was used as a negative control.

\subsection{Statistical Analysis}

Microsoft Excel was used to analyze the mean values and standard errors. The significant differences between controls and treatments or between time points were calculated by the Student's t-test using SPSS 23 (SPSS Inc., Chicago, IL, USA).

\section{Results}

\subsection{TaYS1A Expression is Induced upon Avirulent Pst Infection and SA Treatment}

Recently, Kumar, et al. [59] identified a total of 26 putative wheat $Y S L$ genes. The present study is principally focused on the wheat $Y S L$ gene, TaYS1A. We obtained the CDNA sequence by RT-PCR from wheat cultivar Su11. We found TaYS1A in the same clade with AtYSL3 and its closest homolog HvYS1 in barley (Figure S1). The full-length of TaYS1A (accession number: TraesCS6B02G283800) encodes a protein containing 678 amino acids with a molecular weight of $74.56 \mathrm{kDa}$ and an isoelectric point (pI) 9.15. BlastN search in the hexaploid wheat genome database identified three copies of TaYS1A with $98.97 \%$ nucleotide coding sequence similarities. Therefore, considering high nucleotide coding sequence identity, TaYS1A in chromosome $6 \mathrm{~B}$ was selected as a representative of three copies for further study. To investigate the role of TaYS1A, we further analyzed relative transcript profiles of TaYS1A in Pst inoculated and mock plants at different time points by qRT-PCR. The transcription of TaYS1A was significantly up-regulated at 6 to $48 \mathrm{~h}$ post-inoculation (hpi) and attained a peak of approximately 4.1-fold at $12 \mathrm{hpi}$ in wheat leaves infected by CYR23 isolate over the control plants (Figure 1a). 
(a)

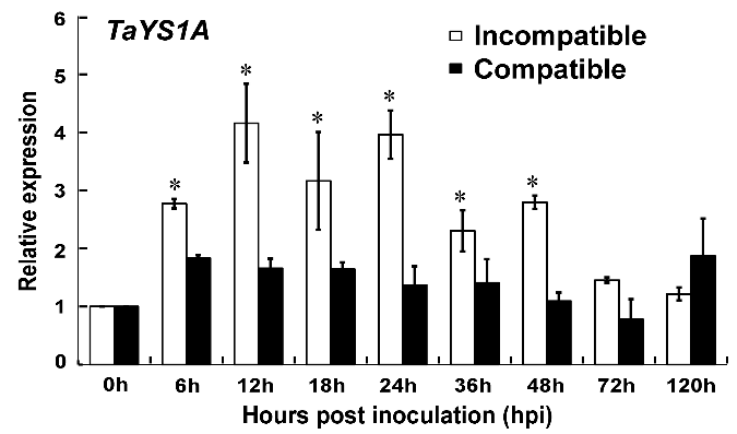

(b)

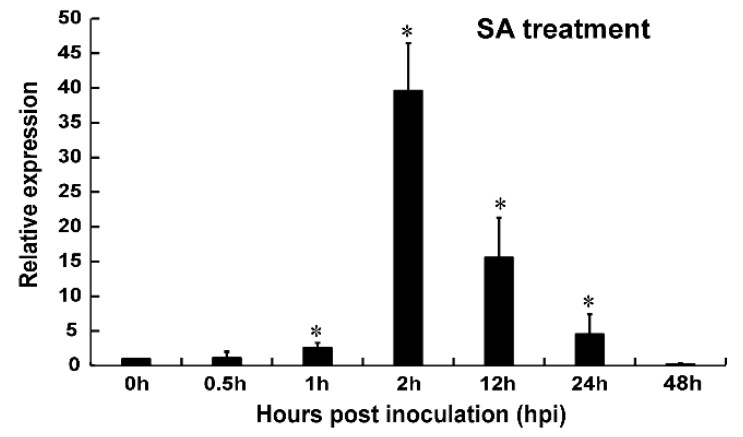

Figure 1. Analysis of TaYS1A expression in Puccinia striiformis f. sp. tritici (Pst) inoculated and salicylic acid (SA) treated wheat leaves. (a) Pst isolates CRY23 and CRY31 inoculated wheat leaves were sampled at various times, representing different stages of $P$ st infection. The mock was inoculated at 0 hpi. (b) Endogenous SA induces TaYS1A transcription. Wheat leaves sprayed with $10 \mathrm{mM} \mathrm{SA}$ and sampled at $0,0.5,1,2,12,24$, and 48 -h post treatment (hpt). The comparative threshold $\left(2^{-\Delta \Delta C T}\right)$ approach was used to measure the relative transcript levels of TaYS1A. Data normalized with the transcription of wheat elongation factor, TaEF-1 $\alpha$, and visualized as fold change compared to control at $0 \mathrm{~h}$. Each data point represents a mean \pm the standard error of three independent biological repetitions. Asterisks denote significant difference $(p<0.05)$ from 0 hpi/hpt by the Student's $t$-test.

Previous studies demonstrated that the expression of TaYS1A protein was tissue-specific in higher plants. We analyzed TaYS1A transcripts from various wheat tissues by qRT-PCR analysis to examine the tissue-specific expression in wheat. TaYS1A expression was detected in all tissues examined (root, stem, and leaf). The TaYS1A transcripts were significantly higher in roots and leaves than stems tissue (Figure S2a). To explore the roles of TaYS1A in hormone perception and signaling, we treated wheat seedlings with different phytohormones, including ABA, SA, ethylene (ET), and jasmonic acid (JA). After treating with SA, the expression of TaYS1A was significantly up-regulated at $1 \mathrm{~h}$ after treatment and attained a peak of approximately 39 -fold at $2 \mathrm{~h}$ post-treatment (Figure $1 \mathrm{~b})$. When treated with MeJA, the transcription of TaYS1A was significantly downregulated at 6 to 24 h post-treatment (Figure S2b).

Since the TaYS1A expressions were significantly different in the incompatible interaction, SA-treatment, and MeJA treatment compared to the controls, we hypothesized that TaYS1A could be one of the positive regulators of wheat resistance to Pst infections. Further experiments were conducted accordingly to examine this hypothesis.

\subsection{TaYS1A Encodes a Plasma Membrane-Targeted Protein}

In wheat, Kumar, et al. [59] predicted that most of the YSL proteins would be localized to the plasma membrane, with the remaining YSLs in the cytoplasm, chloroplast, vacuole, and mitochondria. To examine the subcellular localization of TaYS1A, transient overexpression of recombinant TaYS1A-GFP was achieved in wheat mesophyll protoplasts and $N$. benthamiana leaves. Under the fluorescence microscope, cells transfected with the empty GFP (control) vector displayed fluorescence throughout the cell, including the nucleus, whereas in the wheat protoplasts and $N$. benthamiana cells overexpressing TaYS1A-GFP, we observed fluorescence only on the plasma membrane (Figure 2). 

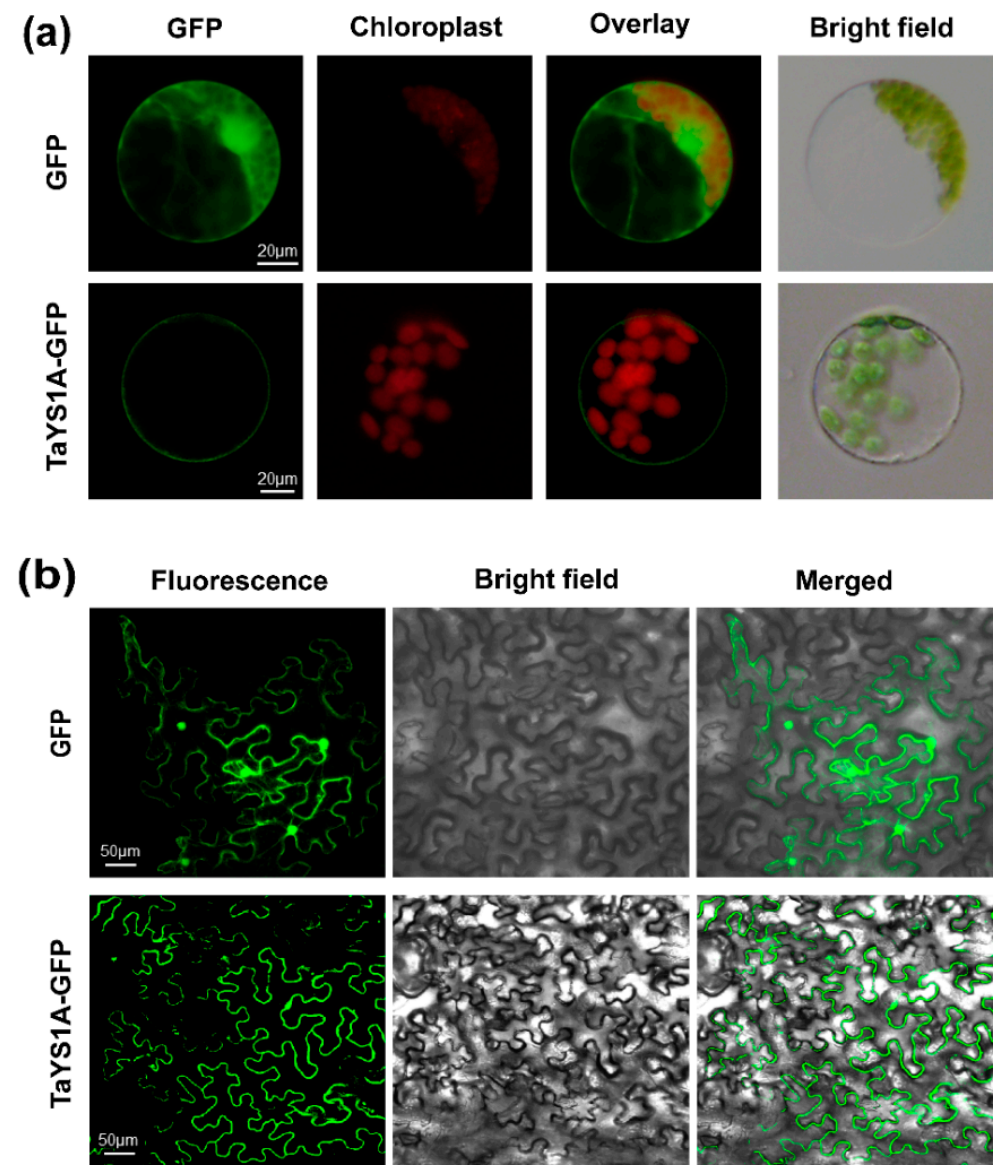

Figure 2. TaYS1A protein subcellular localization assays. (a) The PEG-mediated transformation was used to overexpress Green Fluorescent Protein (GFP) or TaYS1A-GFP fused proteins in wheat protoplasts. (b) GFP or TaYS1A-GFP construct were transformed into A. tumefaciens and then infiltrated into $N$. bentamiana leaves. The GFP autofluorescence was imaged using an Olympus FV1000 confocal microscope with a $488 \mathrm{~nm}$ filter.

\subsection{Transient Silencing of TaYS1A Enhances Wheat Susceptibility to Pst}

To determine the role of TaYS1A in the wheat resistant responses to Pst, we used BSMV-VIGS (virus-induced gene silencing), an effective and rapid gene-silencing method to analyze functions of the wheat and barley genes [60]. At ten-days post-inoculation, mosaic symptoms of the virus were observed in virus-inoculated plants, but further leaf growth was not affected. In contrast, BSMV:TaPDS-as inoculated plants gradually displayed photobleaching symptoms (Figure 3a), suggesting that the virus-induced gene silencing was successfully achieved. The phytoene desaturase (PDS) is required to protect plant chlorophyll from photo-bleaching and silencing of the PDS gene in monocot plants; lack of the PDS gene caused loss of chlorophyll pigmentation (photo-beaching) [52,61]. Thus, the fragment of wheat phytoene desaturase (TaPDS) was inserted into the BSMV vector to construct BSMV: TaPDS and was used as a positive visual control. qRT-PCR results revealed that the transcript levels of endogenous TaYS1A of the transformants were significantly reduced during incompatible and compatible interactions (Figure 3b). The copies of TaYS1A were highly identical, due to the expression level of individual copies which could not be analyzed by qRT-PCR (Figure S3). Remarkably, after inoculation with avirulent CYR23, all leaves expressed HR symptoms, whereas leaves pre-infected with BSMV:TaYS1A-1/2as were found to have few uredia of fungus around the HR. Control plants, BSMV: $\gamma$, and mock expressed only slight HR symptoms (Figure 3c). After inoculation with the virulent race CYR31, fungal growth was slightly increased on BSMV:TaYS1A-1/2as plants compared to the control BSMV: $\gamma$ and compared to mock plants (Figure 3d). 
(a)

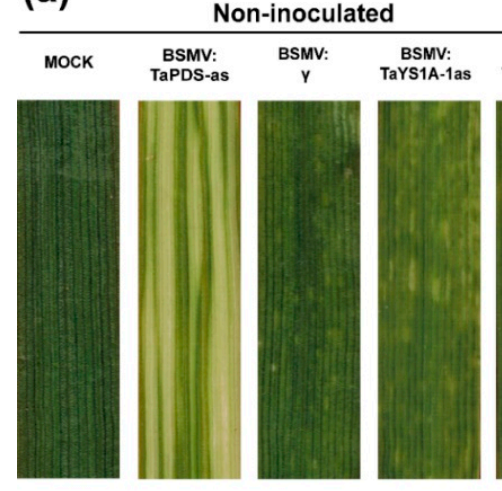

(c)

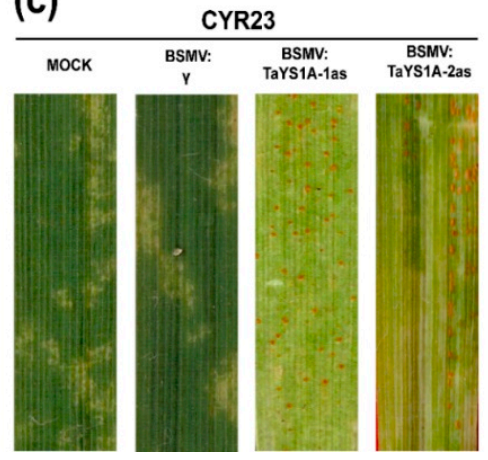

(b)
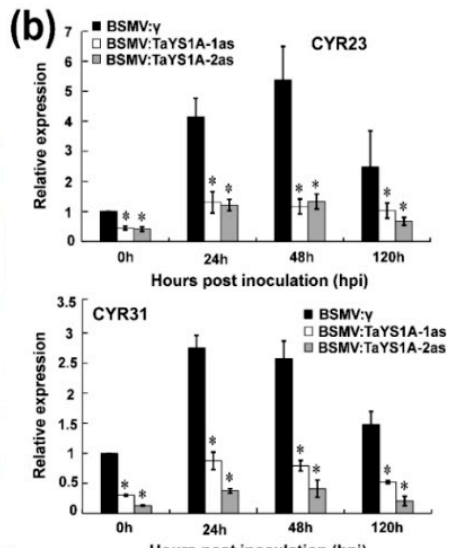

(d) CYR31

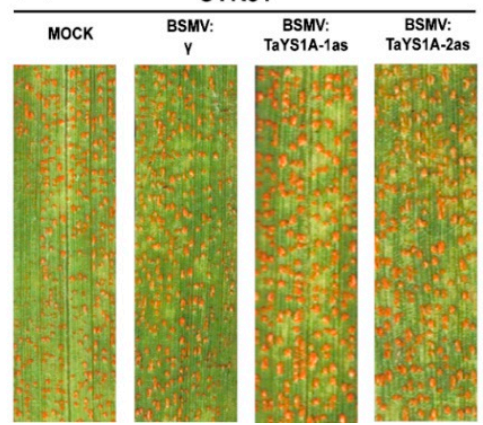

Figure 3. BSMV-mediated gene silencing (VIGS) of TaYS1A enhances wheat susceptibility to Pst. (a) At $10 \mathrm{dpi}$, chlorotic mosaic symptoms were observed on virus-inoculated leaves. Mock, second leaves of wheat seedlings were mechanically rubbed with $1 \times$ Fes buffer. (b) Relative expression of TaYS1A in TaYS1A-silenced plants infected with the avirulent race CRY23 or virulent race CRY31, respectively. The comparative threshold $\left(2^{-\Delta \Delta C T}\right)$ approach was used to measure the relative transcript levels of TaYS1A. Data normalized with the transcription of wheat elongation factor, TaEF- $1 \alpha$, and visualized as fold change compared to control at $0 \mathrm{~h}$. BSMV: $\gamma$ infected wheat leaves were used as a control. Values represent the mean \pm standard errors of three independent biological samples. Asterisks designate significant differences $(p<0.05)$ from BSMV: $\gamma$ by the Student's $t$-test. $(\mathbf{c}, \mathbf{d})$ Photographs of the fourth leaves infected with urediniospores of CRY23 (c) and CRY31 (d) were taken at $14 \mathrm{dpi}$.

We also microscopically examined TaYS1A-silenced leaves infected with CYR23 and CYR31 Pst isolates. At 48 hpi wheat leaves infected with CYR23 at hyphal length significantly increased in TaYS1A-silenced plants in relation to BSMV: $\gamma$ infected plants, and the infected area significantly expanded in TaYS1A-silenced plants at 120 hpi (Figure 4a-e), indicating that the suppression of TaYS1A transcription increased host susceptibility during incompatible wheat and Pst interactions. During CYR31 infection, as compared to the control plants, hyphal length in TaYS1A-silenced plants also significantly increased at $48 \mathrm{hpi}$, and the infection area also significantly expanded at $120 \mathrm{hpi}$ (Figure S4a-c). Taken collectively, our results suggest that the silencing of TaYS1A in wheat benefits the growth and development of $P s t$, and thus increases wheat susceptibility to both avirulent and virulent isolates of Pst. 

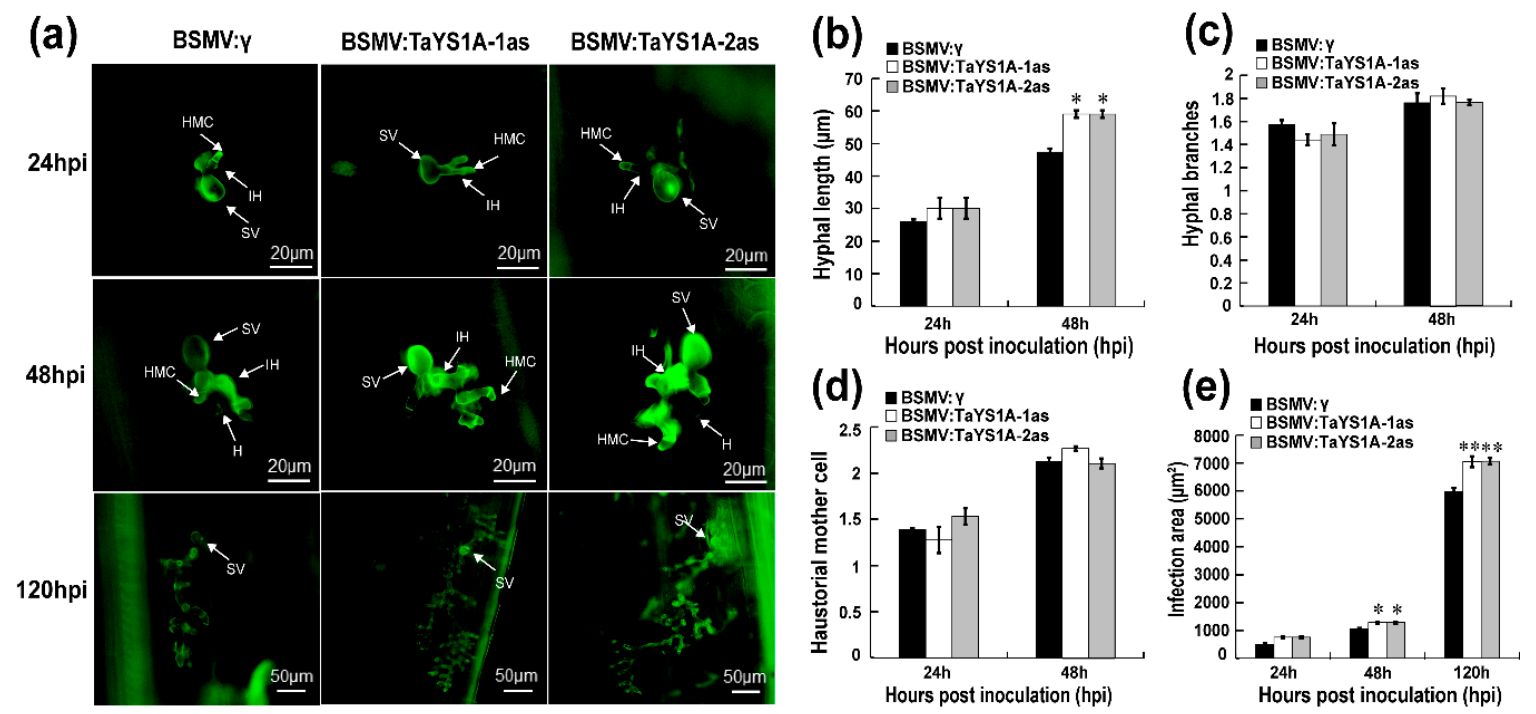

Figure 4. Histology of Pst avirulent race CYR23 in TaYS1A-silenced leaves. (a) Wheat germ agglutinin (WGA) was used to visualize fungal structures in wheat leaves infected with BSMV and Pst and the fungal structures were observed under an autofluorescence microscope. SV, sub-stomatal vesicle; HMC, haustorial mother cell; IH, infection hypha. H, haustoria. (b) Hyphal length is the average distance to the tip of the hypha from the intersection of the sub-stomatal vesicle and the hypha and was measured using DP-BSW (units in $\mu \mathrm{m}$ ) program (Olympus Corporation, Tokyo, Japan). (c) The average number of hyphal branches was estimated for each infection site. (d) The average number of haustorial mother cells in each infection site was determined. (e) Infection area is the average of developing hyphae, and was measured using the DP-BSW program (units in $\mu \mathrm{m}^{2}$ ). All findings were derived from three biological repetitions and each replication considered 50 sites of infection. Asterisks $(p<0.05)$ or double asterisks $(p<0.01)$ designate significant differences compared to the control plants at the same time points, using the Student's $t$-test.

\section{4. $\mathrm{H}_{2} \mathrm{O}_{2}$ Accumulation and PR Transcription Are Affected in TaYS1A-Silenced Plants}

We microscopically examined the TaYS1A-silenced leaves infected with CYR23 and CYR31 to explore why TaYS1A-silenced leaves were more susceptible to Pst. Our results revealed that the accumulation of $\mathrm{H}_{2} \mathrm{O}_{2}$ was significantly decreased in TaYS1A-silenced leaves as compared to the control leaves at 48 and 120 hpi during incompatible interactions (Figure 5a,b). Moreover, the necrotic cells per infection site of the TaYS1A-silenced leaves also decreased significantly at 48 and $120 \mathrm{hpi}$, compared to the control plant leaves (Figure $5 \mathrm{a}, \mathrm{c}$ ). These results indicate that increased susceptibility of wheat to Pst after silencing of TaYS1A seems to rely on ROS. 
(a)

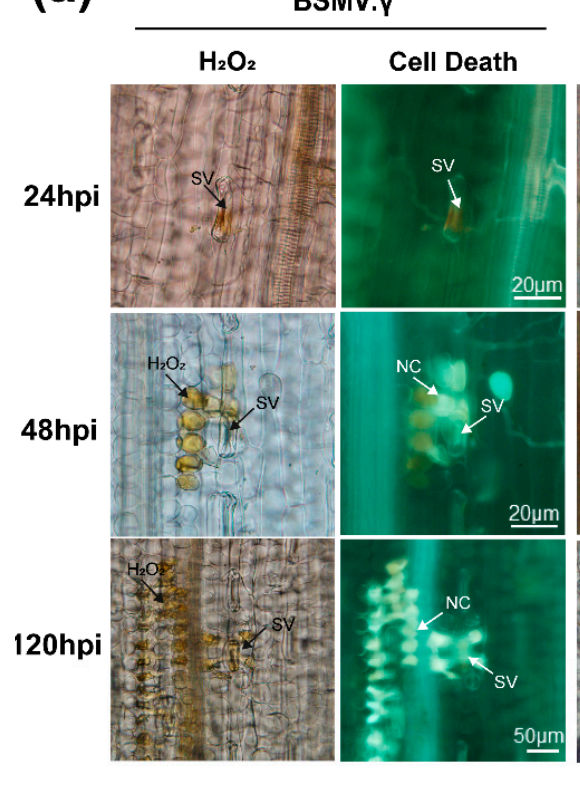

(b)

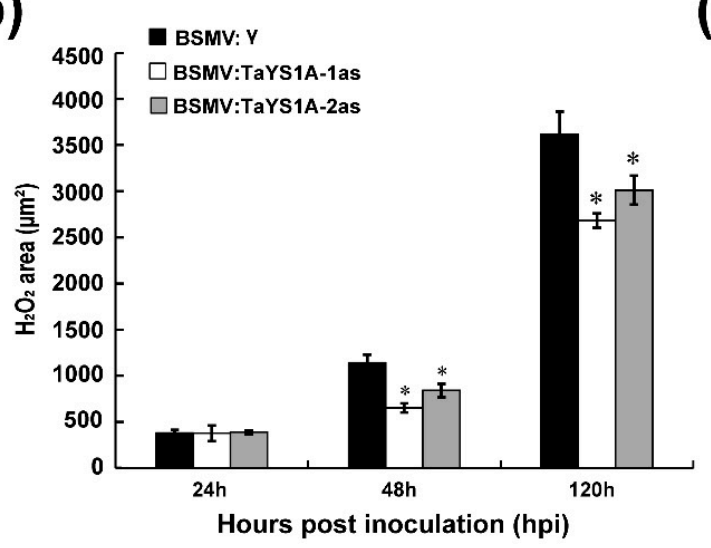

BSMV:TaYS1A-1as
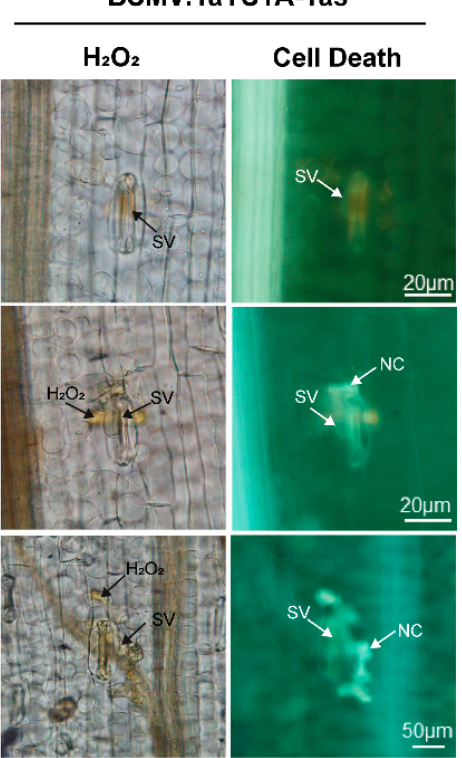

BSMV:TaYS1A-2as

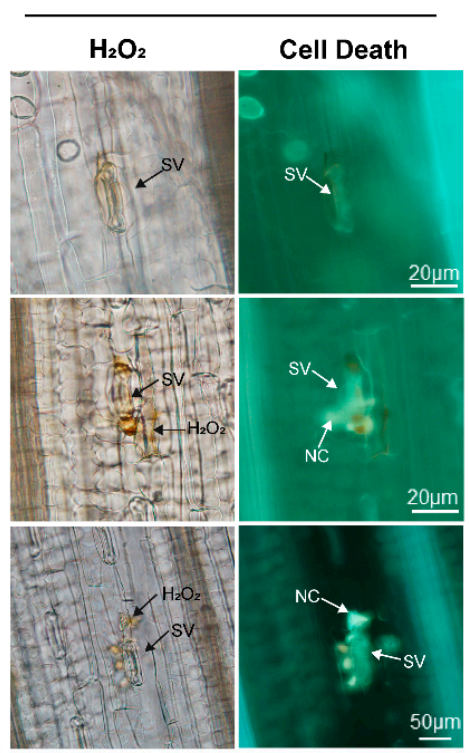

(c)

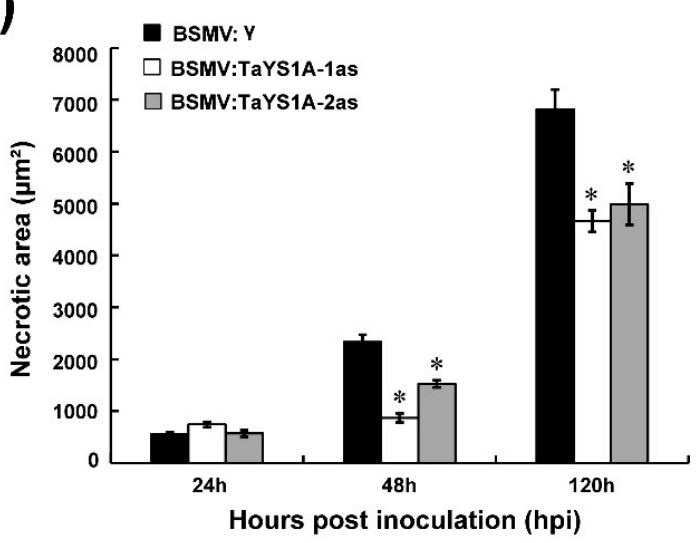

Figure 5. $\mathrm{H}_{2} \mathrm{O}_{2}$ accumulation in TaYS1A-silenced leaves was reduced when infected with Pst avirulent race CYR23. (a) Histological observation of wheat leaves inoculated with BSMV and infected with CYR23. Wheat leaves pre-infected with BSMV: $\gamma$ or BSMV:TaYS1A-1/2as were then inoculated with CYR23. 3,3-diaminobenzidine (DAB) was used for $\mathrm{H}_{2} \mathrm{O}_{2}$ detection. The necrosis was detected by autofluorescence and was viewed under differential interference contrast optics. SV, sub-stomatal vesicle; $\mathrm{NC}$, necrotic cell. (b) The amount of $\mathrm{H}_{2} \mathrm{O}_{2}$ production was calculated using DP-BSW tools by measuring the DAB-stained region at each infection site. (c) To calculate necrotic cell death, the fluorescence area was measured. Values denote the mean \pm standard errors of three independent biological samples. Asterisks designate significant differences $(p<0.05)$ from BSMV: $\gamma$ at same time points by the Student's $t$-test.

We further measured the expression of defense-related genes and ROS-related genes in TaYS1A-silenced plants after Pst inoculation. The transcript levels of TaPR1, TaPR2, and the ROS-generating gene, NADH-oxidase (TaNOX), were significantly diminished in TaYS1A-silenced plants relative to the control plants during incompatible interactions (Figure $6 \mathrm{a}-\mathrm{c}$ ). The transcription levels of the ROS-scavenging gene, TaCAT, were significantly up-regulated in TaYS1A-silenced plants inoculated with CYR23 (Figure 6d). When the TaYS1A-silenced plants were challenged by the virulent CRY31, transcript levels of TaPR1 and TaPR2 were also significantly diminished (Figure S5). Altogether, these results suggest that silencing of TaYS1A in wheat enhances Pst growth by restricting the transcription of PR proteins or $\mathrm{H}_{2} \mathrm{O}_{2}$ accumulation. 
(a)

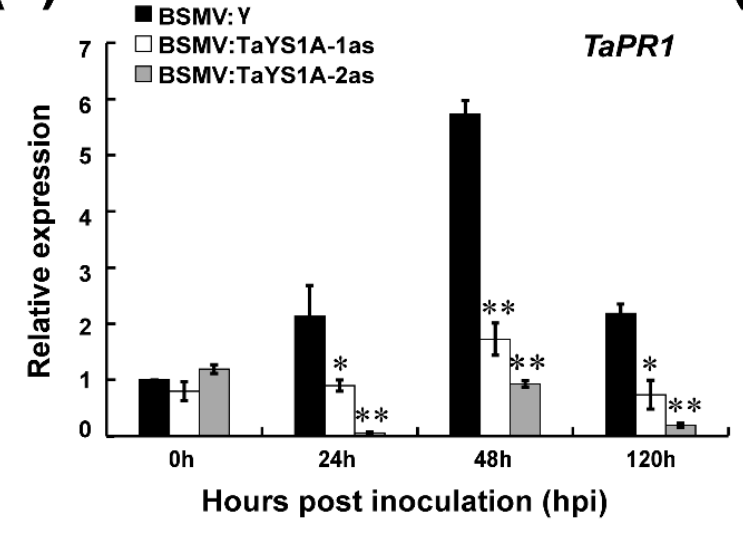

(c)

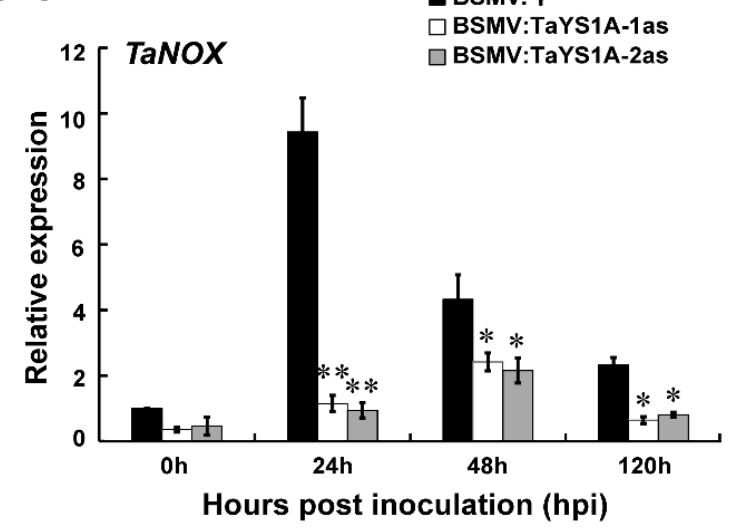

(b)

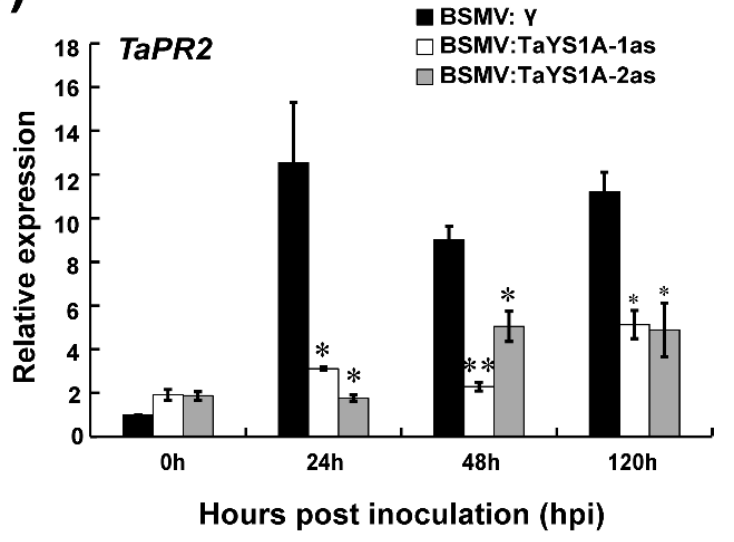

(d)

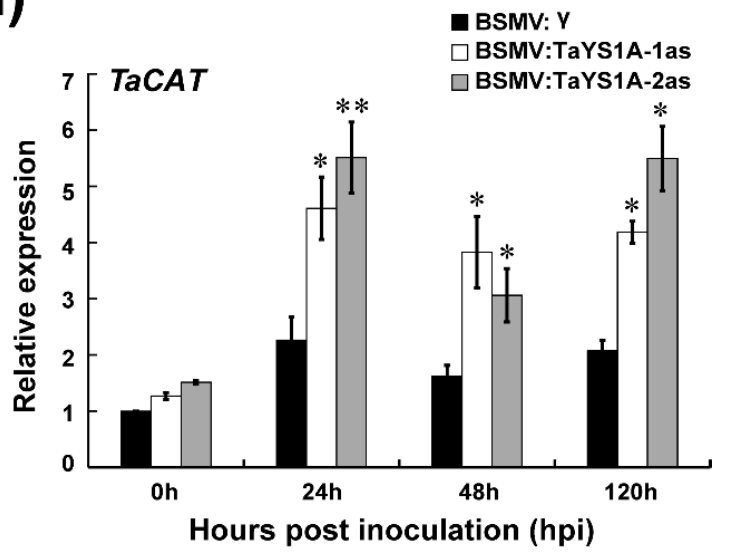

Figure 6. Relative expression of defense and reactive oxygen species (ROS) related marker genes in TaYSIA-silenced plants infected with Pst avirulent race CYR23 (a) The relative expression of TaPR1 (pathogenesis-related gene 1). (b) The relative expression of TaPR2 ( $\beta$-1,3-glucanase). (c) The relative expression of TaNOX (NADPH oxidase) (d) The relative expression of TaCAT (catalase). The qRT-PCR was used to analyze the relative expression of all genes. The comparative threshold $\left(2^{-\Delta \Delta C T}\right)$ approach was used to measure the relative transcript levels of TaYS1A. Data normalized with the transcription of wheat elongation factor, TaEF-1 $\alpha$, and visualized as fold change compared to control at $0 \mathrm{~h}$. BSMV: $\gamma$ infected wheat leaves were used as a control. Values represent the mean \pm standard errors of three independent biological samples. Asterisks $(p<0.05)$ or double asterisks $(p<0.01)$ designate significant differences from BSMV: $\gamma$ by the Student's $t$-test.

\subsection{Fungal Biomass and SA Level in TaYS1A-Silenced Plants}

To analyze the fungal biomass in TaYS1A-silenced leaves, total genomic DNA was extracted from the CYR23- and CYR31-inoculated leaves sampled at 14 days post-inoculation (dpi), and the biomass ratio was analyzed by qRT-PCR. The fungal biomass was found significantly increased in the TaYS1A-silenced leaves infected with CYR23 compared to the control plants (Figure 7a). In the TaYS1A-silenced leaves infected with CYR31, the fungal biomass was also slightly increased compared to the control plants.

Moreover, we measured the SA level in TaYS1A-silenced plants to determine whether the suppression of the TaYS1A gene affected the SA level and thereby led to the increased susceptibility to Pst. Our results showed that silencing of TaYS1A significantly reduced the endogenous SA concentration compared to control plants (Figure 7b). 
(a)

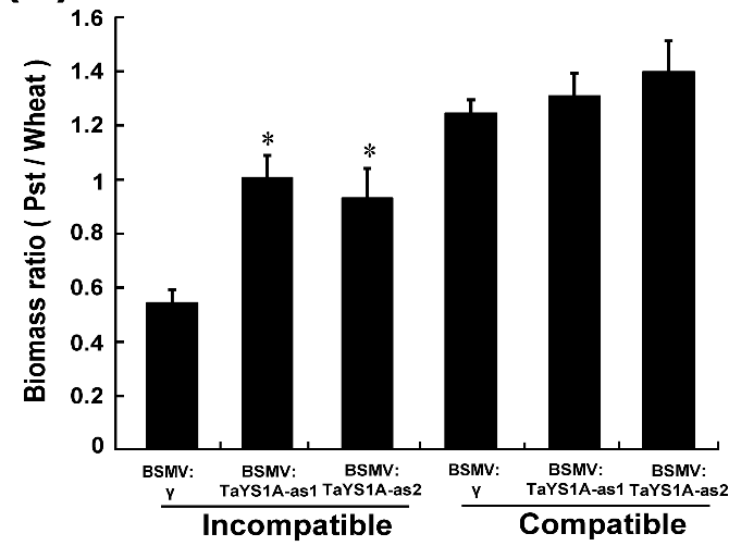

(b)

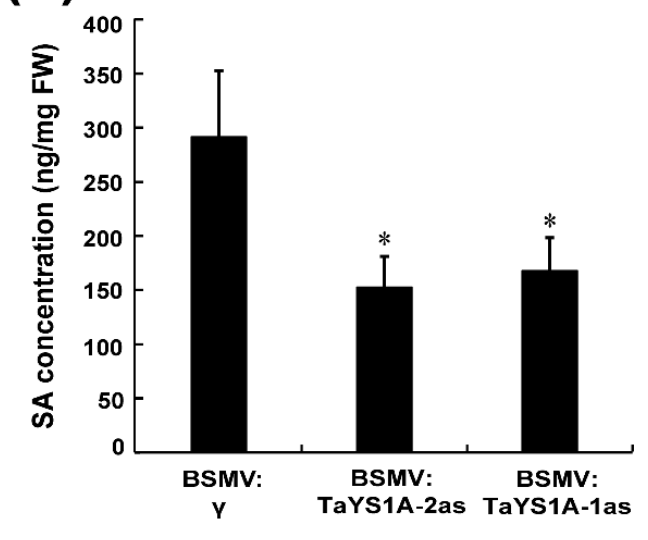

Figure 7. Fungal biomass and SA quantification in TaYS1A-silenced plants. (a) Relative fungal biomass was measured from the total genomic DNA of TaYS1A-silenced leaves infected with CYR23 or CYR31, which was sampled at 14 dpi. (b) SA concentration in TaYS1A-silenced leaves infected with CYR23, which was sampled at $14 \mathrm{dpi}$. Values denote the mean \pm standard errors of three independent biological samples. Asterisks indicate significant differences from BSMV: $\gamma$ using the Student's $t$-test $(p<0.05)$.

\subsection{TaYS1A Interacts with TaNH2}

Chen, et al. [38] reported that YSL genes function as downstream elements of SA signaling in an NPR1-dependent pathway. Based on this demonstration, we assumed that TaYS1A might directly interact with NPR1 or NPR1-homologous proteins. To explore our speculation, we selected TaNH2, an orthologue of AtNPR3/4, which showed a positive function in wheat resistance to Pst [11], and cloned it in pGADT7 vector. The constructs, pGBKT7-TaYS1A, and pGADT7-TaNH2 plasmids were then co-transformed into the yeast strain AH109 cultured on the selection medium SD/-Trp/-Leu/-His/-Ade and X- $\alpha$-gal. We found that TaYS1A strongly interacted with TaNH2 (Figure 8a).

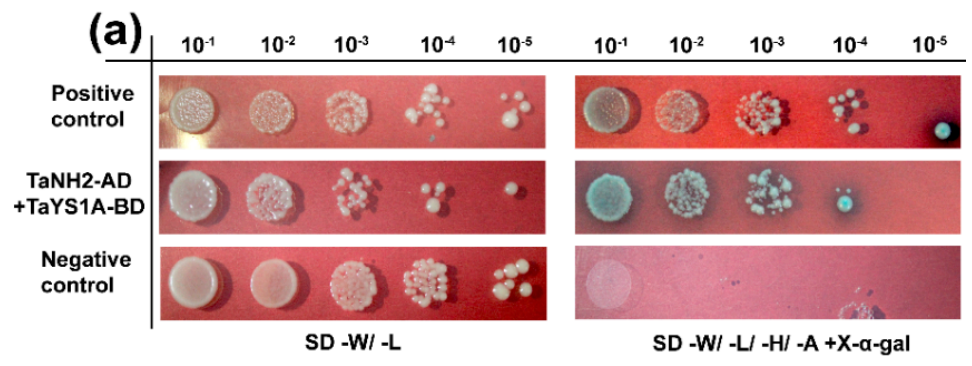

(b)

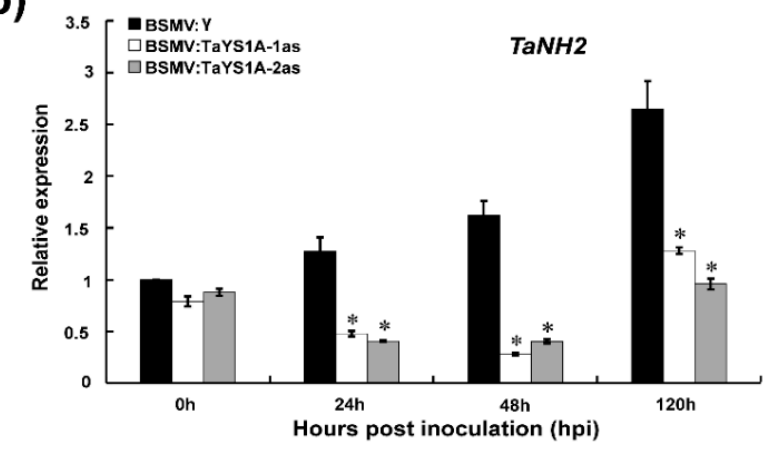

Figure 8. Interaction between TaYS1A and TaNH2. (a) Y2H interaction analysis between TaYS1A and TaNH2 in yeast. The constructed TaYS1A-BD interacts with TaNH2-AD in yeast. Cells of yeast strain 
AH109 containing the indicated pairs of plasmids were cultured on selective media SD-W/-L or SD-

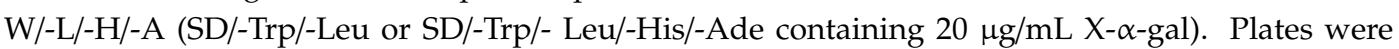
photographed 3 dpi. SD, synthetic dropout growth medium. (b) Silencing of TaYS1A suppresses the transcription of $\mathrm{TaNH} 2$. Relative expression of $\mathrm{TaNH} 2$ in TaYS1A-silenced leaves inoculated with CYR23 was determined by qRT-PCR. The qRT-PCR was used to analyze the relative expression of all genes. The comparative threshold $\left(2^{-\Delta \Delta C T}\right)$ approach was used to measure the relative transcript levels of TaYS1A. Data normalized with the transcription of wheat elongation factor, TaEF-1 $\alpha$, and visualized as fold change compared to control at 0h. BSMV: $\gamma$ infected wheat leaves were used as a control. Values represent the mean \pm standard errors of three independent biological samples. Asterisks $(p<0.05)$ designate significant differences from BSMV: $\gamma$ by the Student's $t$-test.

To determine whether the silencing of TaYS1A affected the expression of TaNH2, we further analyzed the transcript level of TaNH2 in TaYS1A-silenced plants by qRT-PCR. We found that the expression of TaNH2 was significantly downregulated in the TaYS1A-silenced plants infected with CYR23 compared to the control plants (Figure 8b).

\section{Discussion}

The YSL-protein-family plays a key role in plants, particularly in the mobilization and long-distance transportation of micronutrients. YSL proteins were also found to be affected by the SA level and involved in the host defense against pathogens [38,62]. To date, the metal transportation ability of YSLs has been identified and characterized in different plant species, including Arabidopsis, rice, maize, and Brachypodium [63-65]. However, the biological functions of YSL proteins in pathogen induced defense are largely unknown, particularly in wheat defense against Pst infections. In our present study, we cloned a wheat YSL subfamily gene, TaYS1A, and characterized its molecular function during wheat-Pst interaction. The expression of TaYS1A was strongly induced when inoculated with Pst avirulent race CYR23 and SA treatment. Silencing of TaYS1A enhanced the susceptibility to both avirulent and virulent $P s t$ races. The reduced expression of $P R$-genes and SA accumulation suggests that TaYS1A exhibits a positive role in wheat resistance to Pst.

YSLs are members of the OPT family, representing the largest subgroup of transmembrane proteins that are mainly involved in the transfer of a wide variety of substrates [31]. In wheat, a total of 26 genes of the YSL subfamily were previously identified. Most of the YSL genes were predicted to be plasma-membrane localized proteins, whose expressions were induced under Fe-limited conditions [59]. Our results revealed that TaYS1A localized in the plasma membrane of wheat protoplasts and $N$. bethamiana cells. Usually, many pathogenesis-related proteins are thought to be secreted into the apoplast to evade pathogenic infections by their defensive mechanism. Some of those proteins directly recognize and interact with the pathogens that exist in the plasma membrane $[66,67]$. Accordingly, we hypothesized that the presence of TaYS1A in the plasma-membrane might have a significant function in defense responses against pathogenic infection. However, the induction of SA might be required for the activation of TaYS1A in the plasma-membrane as endogenous SA treatment could significantly induce the expression of TaYS1A. SA has been confirmed to be synthesized by the plant in response to a diverse range of pathogens and it was also reported that SA is induced by Pst infection in wheat [8,11], suggesting the involvement of TaYS1A in the SA signaling pathway. Furthermore, we found that the expression of TaYS1A was significantly induced during wheat-Pst incompatible interaction. Thus, upon the infection of CYR23 and SA treatment in wheat leaves the expression of TaYS1A was significantly up-regulated, implying its crucial functions in wheat defense against Pst.

ROS have been proposed to play a key role in the establishment of plant defense followed by programmed cell death (PCD) $[6,68]$ and are very effective against fungal infection. Specifically, $\mathrm{H}_{2} \mathrm{O}_{2}$ seems to elicit localized cell death and signals induction of pathogenesis-related genes and antioxidants in nearby plant cells during fungal infections [6,69]. Moreover, SA is a signaling molecule involved in basal and SAR with the activation of HR during infection caused by biotrophic 
pathogens [2,70]. HR occurs at or near the entry site after pathogen infection, followed by ROS production and SA accumulation. In addition to ROS production, SA can also inhibit ROS-scavenging by activating certain antioxidants, which ultimately contribute to the initiation of PCD at infection sites [8,71-73]. We used the VIGS method to explore the role of TaYS1A in the interaction between wheat and Pst. During the avirulent Pst CYR23 infections, TaYS1A-silenced plants were more susceptible, accompanied by decreased ROS accumulation and necrotic cell death, increased hyphal length, and expanded infection area, indicating that suppressing the expression of TaYS1A diminished wheat resistance to avirulent Pst infection. The transcript expression of ROS generating TaNOX, was also significantly reduced in TaYS1A-silenced plants infected with Pst CYR23, suggesting that TaYS1A regulated the wheat defense against Pst infection through the ROS-dependent pathway. Importantly, the increase of fungal biomass and the decrease in SA accumulation in TaYS1A-silenced plants infected with CYR23 further suggests that TaYS1A performs a positive regulatory function of wheat defense against $P s t$ by modulating the SA signaling pathway. In contrast, the transcript level of ROS scavenging gene, TaCAT, was significantly upregulated after the silencing of TaYS1A, ultimately resulting in less ROS accumulation and promoting Pst infection. The reduction of ROS accumulation might have occurred due to the reduced SA accumulation in TaYS1A-silenced plants, which prevented inhibition of the ROS scavenging system. However, the mechanism by which TaYS1A modulates SA signaling or the ROS-dependent pathway to restrict $P s t$ infection in wheat is unclear.

NPR1 is the key positive SAR regulator and plays a crucial function in SA signal transduction to induce $P R$ gene expression in Arabidopsis [74,75]. NPR1 is a receptor of SA and transcriptional coregulator of SA-dependent defense-related gene activation $[39,40]$. The expression of TaNH2, an AtNPR3/4 orthologous gene, was induced by Pst infection and thereby performed a positive regulatory function in the resistance of wheat to Pst [11]. Our results revealed that TaYS1A directly interacted with TaNH2, and silencing of TaYS1A significantly reduced the transcript level of TaNH2. The transcript levels of TaPR1 and TaPR2 were also significantly diminished in TaYS1A-silenced leaves after infection with either CYR23 or CYR31. AtYSL3 was reported to be induced by SA and required for pathogen defense in an NPR1-dependent pathway [38]. Thus, our results suggested that TaYS1A modulates SA signaling through the TaNH2 activity that induces the transcription of SA-dependent defense-related genes and therefore increases wheat resistance against $P$ st.

In summary, our findings revealed that TaYS1A possibly functions as a positive wheat stripe rust resistance regulator by modulating the SA-signaling pathway via ROS-dependent signals. After pathogen invasion, plant biosynthesis SA serves as a part of pathogen defense, which may induce the transcription of TaYS1A to regulate SA-dependent signaling through ROS accumulation and defense-related gene expression. We further identified that TaYS1A directly interacts with TaNH2. NPR1 genes are the central coregulator of defense-related gene activation in SA-signaling pathway and Fe acquisition and homeostasis could induce a burst of ROS during pathogen infection in plants $[41,76]$. We therefore hypothesize that the transcription of TaYS1A is activated by TaNH2 by the induction of SA and the metal ion homeostasis function of TaYS1A performs a role in ROS accumulation leading to HR response in plant immunity against pathogen infection. Further studies are required to confirm our hypothesis. To our knowledge, this is the first report suggesting that a wheat YSL gene positively regulates the resistance against $P$ st infection, which expands our understanding toward the biological role of the TaYS1A gene, ranging from metal translocation to pathogen defense.

Supplementary Materials: Supplementary materials can be found at http://www.mdpi.com/2073-4425/11/12/ 1452/s1. Figure S1: Phylogenetic analysis of TaYS1A and its homologs, Figure S2: Transcript profile of TaYS1A in different wheat tissues and hormone treatments, Figure S3: Multiple sequence alignment of the coding sequences of the TaYS1A copies, Figure S4: Growth of Pst virulent race CYR31 is reduced in TaYS1A-silenced plants, Figure S5: Host response of TaYS1A-silenced plants inoculated with Pst virulent race CRY31, Table S1: Primers used in this study.

Author Contributions: J.G. (Jun Guo) and Z.K. designed experiments; M.A.I. performed most of the experiments with the assistance of H.P., S.T., X.B. and H.Z.; M.A.I. and J.G. (Jia Guo) analyzed the data; M.A.I., J.G. (Jia Guo) and J.G. (Jun Guo) wrote the manuscript. All authors have read and agreed to the published version of the manuscript. 
Funding: This study was supported by National Transgenic Key Project of the Ministry of Agriculture of China (2020ZX08009-15B), National Natural Science Foundation of China (31972224), National Key R\&D Program of China (2018YFD0200402), Natural Science Basic Research Program of Shaanxi (2020JZ-13) and the 111 Project from the Ministry of Education of China (No. B07049). The funders played no role in the design of the study and collection, analysis, and interpretation of data and in writing the manuscript.

Acknowledgments: The authors acknowledge Larry Dunkle from the USDA-Agricultural Research Service at Purdue University USA for critical reading of the manuscript.

Conflicts of Interest: The authors declare no conflict of interest.

\section{References}

1. Wan, A.; Zhao, Z.; Chen, X.; He, Z.; Jin, S.; Jia, Q.; Yao, G.; Yang, J.; Wang, B.; Li, G. Wheat stripe rust epidemic and virulence of Puccinia striiformis f. sp. tritici in China in 2002. Plant Dis. 2004, 88, 896-904.

2. Tsuda, K.; Katagiri, F. Comparing signaling mechanisms engaged in pattern-triggered and effector-triggered immunity. Curr. Opin. Plant Biol. 2010, 13, 459-465. [CrossRef]

3. Boller, T.; Felix, G. A Renaissance of elicitors: Perception of microbe-associated molecular patterns and danger signals by pattern-recognition receptors. Annu. Rev. Plant Biol. 2009, 60, 379-406. [CrossRef]

4. Schulze-Lefert, P. Plant immunity: The origami of receptor activation. Curr. Biol. 2004, 14, R22-R24. [CrossRef]

5. Mittler, R.; Vanderauwera, S.; Gollery, M.; Van Breusegem, F. Reactive oxygen gene network of plants. Trends Plant Sci. 2004, 9, 490-498. [CrossRef]

6. Levine, A.; Tenhaken, R.; Dixon, R.; Lamb, C. $\mathrm{H}_{2} \mathrm{O}_{2}$ from the oxidative burst orchestrates the plant hypersensitive disease resistance response. Cell 1994, 79, 583-593. [CrossRef]

7. Fu, Z.Q.; Yan, S.; Saleh, A.; Wang, W.; Ruble, J.; Oka, N.; Mohan, R.; Spoel, S.H.; Tada, Y.; Zheng, N. NPR3 and NPR4 are receptors for the immune signal salicylic acid in plants. Nature 2012, 486, 228-232. [CrossRef]

8. Vlot, A.C.; Dempsey, D.M.A.; Klessig, D.F. Salicylic acid, a multifaceted hormone to combat disease. Annu. Rev. Phytopathol. 2009, 47, 177-206. [CrossRef]

9. Yuan, Y.; Zhong, S.; Li, Q.; Zhu, Z.; Lou, Y.; Wang, L.; Wang, J.; Wang, M.; Li, Q.; Yang, D. Functional analysis of rice NPR1-like genes reveals that OsNPR1/NH1 is the rice orthologue conferring disease resistance with enhanced herbivore susceptibility. Plant Biotechnol. J. 2007, 5, 313-324. [CrossRef]

10. Bai, W.; Chern, M.; Ruan, D.; Canlas, P.E.; Sze-to, W.H.; Ronald, P.C. Enhanced disease resistance and hypersensitivity to BTH by introduction of an NH1/OsNPR1 paralog. Plant Biotechnol. J. 2011, 9, 205-215. [CrossRef]

11. Liu, P.; Guo, J.; Zhang, R.; Zhao, J.; Liu, C.; Qi, T.; Duan, Y.; Kang, Z.; Guo, J. TaCIPK10 interacts with and phosphorylates TaNH2 to activate wheat defense responses to stripe rust. Plant Biotechnol. J. 2019, 17, 956-968. [CrossRef] [PubMed]

12. Morrissey, J.; Guerinot, M.L. Iron uptake and transport in plants: The good, the bad, and the ionome. Chem. Rev. 2009, 109, 4553-4567. [CrossRef]

13. Zuo, Y.; Zhang, F. Soil and crop management strategies to prevent iron deficiency in crops. Plant Soil 2011, 339, 83-95. [CrossRef]

14. Winterbourn, C.C. Toxicity of iron and hydrogen peroxide: The Fenton reaction. Toxicol. Lett. 1995, 82, 969-974. [CrossRef]

15. Pierre, J.; Fontecave, M. Iron and activated oxygen species in biology: The basic chemistry. Biometals 1999, 12, 195-199. [CrossRef]

16. Ye, F.; Albarouki, E.; Lingam, B.; Deising, H.B.; von Wirén, N. An adequate Fe nutritional status of maize suppresses infection and biotrophic growth of Colletotrichum graminicola. Physiol. Plant. 2014, 151, 280-292. [CrossRef]

17. Greenshields, D.L.; Liu, G.; Wei, Y. Roles of iron in plant defence and fungal virulence. Plant Signal. Behav. 2007, 2, 300-302. [CrossRef]

18. Liu, G.; Greenshields, D.L.; Sammynaiken, R.; Hirji, R.N.; Selvaraj, G.; Wei, Y. Targeted alterations in iron homeostasis underlie plant defense responses. J. Cell. Sci. 2007, 120, 596-605. [CrossRef]

19. Torres, M.A.; Jones, J.D.; Dangl, J.L. Reactive oxygen species signaling in response to pathogens. Plant Physiol. 2006, 141, 373-378. [CrossRef] 
20. Torres, M.A.; Dangl, J.L.; Jones, J.D. Arabidopsis gp91 ${ }^{\text {phox }}$ homologues AtrbohD and AtrbohF are required for accumulation of reactive oxygen intermediates in the plant defense response. Proc. Natl. Acad. Sci. USA 2002, 99, 517-522. [CrossRef]

21. McDowell, J.M.; Dangl, J.L. Signal transduction in the plant immune response. Trends Biochem. Sci. 2000, 25, 79-82. [CrossRef]

22. Marcec, M.J.; Gilroy, S.; Poovaiah, B.; Tanaka, K. Mutual interplay of $\mathrm{Ca}^{2+}$ and ROS signaling in plant immune response. Plant Sci. 2019, 283, 343-354. [CrossRef]

23. Dangol, S.; Chen, Y.; Hwang, B.K.; Jwa, N.-S. Iron-and reactive oxygen species-dependent ferroptotic cell death in rice-Magnaporthe oryzae interactions. Plant Cell 2019, 31, 189-209. [CrossRef]

24. Stockwell, B.R. Ferroptosis: Death by lipid peroxidation. Free Radic. Biol. Med. 2018, 120, S7. [CrossRef]

25. Scheepers, M.; Spielmann, J.; Boulanger, M.; Carnol, M.; Bosman, B.; De Pauw, E.; Goormaghtigh, E.; Motte, P.; Hanikenne, M. Intertwined metal homeostasis, oxidative and biotic stress responses in the Arabidopsis frd3 mutant. Plant J. 2020, 102, 34-52. [CrossRef]

26. Murata, Y.; Ma, J.F.; Yamaji, N.; Ueno, D.; Nomoto, K.; Iwashita, T. A specific transporter for iron (III)-phytosiderophore in barley roots. Plant J. 2006, 46, 563-572. [CrossRef]

27. Schaaf, G.; Ludewig, U.; Erenoglu, B.E.; Mori, S.; Kitahara, T.; von Wirén, N. ZmYS1 functions as a proton-coupled symporter for phytosiderophore-and nicotianamine-chelated metals. J. Biol. Chem. 2004, 279, 9091-9096. [CrossRef]

28. Curie, C.; Panaviene, Z.; Loulergue, C.; Dellaporta, S.L.; Briat, J.-F.; Walker, E.L. Maize yellow stripe1 encodes a membrane protein directly involved in Fe (III) uptake. Nature 2001, 409, 346-349. [CrossRef]

29. Römheld, V.; Marschner, H. Evidence for a specific uptake system for iron phytosiderophores in roots of grasses. Plant Physiol. 1986, 80, 175-180. [CrossRef]

30. Von Wirén, N.; Mori, S.; Marschner, H.; Romheld, V. Iron inefficiency in maize mutant ys1 (Zea mays L. cv Yellow-Stripe) is caused by a defect in uptake of iron phytosiderophores. Plant Physiol. 1994, 106, 71-77. [CrossRef]

31. Lubkowitz, M. The oligopeptide transporters: A small gene family with a diverse group of substrates and functions? Mol. Plant 2011, 4, 407-415. [CrossRef]

32. Liu, T.; Zeng, J.; Xia, K.; Fan, T.; Li, Y.; Wang, Y.; Xu, X.; Zhang, M. Evolutionary expansion and functional diversification of oligopeptide transporter gene family in rice. Rice 2012, 5, 12. [CrossRef]

33. Stacey, M.G.; Osawa, H.; Patel, A.; Gassmann, W.; Stacey, G. Expression analyses of Arabidopsis oligopeptide transporters during seed germination, vegetative growth and reproduction. Planta 2006, 223, 291-305. [CrossRef]

34. Connorton, J.M.; Jones, E.R.; Rodríguez-Ramiro, I.; Fairweather-Tait, S.; Uauy, C.; Balk, J. Wheat vacuolar iron transporter TaVIT2 transports Fe and Mn and is effective for biofortification. Plant Physiol. 2017, 174, 2434-2444. [CrossRef]

35. Zhai, Z.; Gayomba, S.R.; Jung, H.-i.; Vimalakumari, N.K.; Piñeros, M.; Craft, E.; Rutzke, M.A.; Danku, J.; Lahner, B.; Punshon, T. OPT3 is a phloem-specific iron transporter that is essential for systemic iron signaling and redistribution of iron and cadmium in Arabidopsis. Plant Cell 2014, 26, 2249-2264. [CrossRef]

36. Yoo, C.Y.; Miura, K.; Jin, J.B.; Lee, J.; Park, H.C.; Salt, D.E.; Yun, D.J.; Bressan, R.A.; Hasegawa, P.M. SIZ1 small ubiquitin-like modifier E3 ligase facilitates basal thermotolerance in Arabidopsis independent of salicylic acid. Plant Physiol. 2006, 142, 1548-1558. [CrossRef]

37. Lee, J.; Nam, J.; Park, H.C.; Na, G.; Miura, K.; Jin, J.B.; Yoo, C.Y.; Baek, D.; Kim, D.H.; Jeong, J.C. Salicylic acid-mediated innate immunity in Arabidopsis is regulated by SIZ1 SUMO E3 ligase. Plant J. 2007, 49, 79-90. [CrossRef]

38. Chen, C.C.; Chien, W.F.; Lin, N.C.; Yeh, K.C. Alternative functions of Arabidopsis Yellow Stripe-Like3: From metal translocation to pathogen defense. PLoS ONE 2014, 9, e98008. [CrossRef]

39. Wu, Y.; Zhang, D.; Chu, J.Y.; Boyle, P.; Wang, Y.; Brindle, I.D.; De Luca, V.; Després, C. The Arabidopsis NPR1 protein is a receptor for the plant defense hormone salicylic acid. Cell Rep. 2012, 1, 639-647. [CrossRef]

40. Ryals, J.; Weymann, K.; Lawton, K.; Friedrich, L.; Ellis, D.; Steiner, H.Y.; Johnson, J.; Delaney, T.P.; Jesse, T.; Vos, P. The Arabidopsis NIM1 protein shows homology to the mammalian transcription factor inhibitor I kappa B. Plant Cell 1997, 9, 425-439. [CrossRef]

41. Wang, D.; Amornsiripanitch, N.; Dong, X. A genomic approach to identify regulatory nodes in the transcriptional network of systemic acquired resistance in plants. PLoS Pathog. 2006, 2, e123. [CrossRef] 
42. Fu, Z.Q.; Dong, X. Systemic acquired resistance: Turning local infection into global defense. Annu. Rev. Plant Biol. 2013, 64, 839-863. [CrossRef]

43. Chen, W.Q.; Wu, L.R.; Liu, T.G.; Xu, S.C.; Jin, S.L.; Peng, Y.L.; Wang, B.T. Race Dynamics, diversity, and virulence evolution in Puccinia striiformis f. sp. tritici, the causal agent of wheat stripe rust in china from 2003 to 2007. Plant Dis. 2009, 93, 1093-1101. [CrossRef]

44. Kang, Z.; Huang, L.; Buchenauer, H. Ultrastructural changes and localization of lignin and callose in compatible and incompatible interactions between wheat and Puccinia striiformis. J. Plant Dis. Prot. 2002, 109, 25-37.

45. Duan, Y.H.; Guo, J.; Ding, K.; Wang, S.J.; Zhang, H.; Dai, X.W.; Chen, Y.Y.; Govers, F.; Huang, L.L.; Kang, Z.S. Characterization of a wheat $H S P 70$ gene and its expression in response to stripe rust infection and abiotic stresses. Mol. Biol. Rep. 2011, 38, 301-307. [CrossRef]

46. Livak, K.J.; Schmittgen, T.D. Analysis of relative gene expression data using real-time quantitative PCR and the 2(-Delta Delta C(T)) Method. Methods 2001, 25, 402-408. [CrossRef]

47. Paolacci, A.R.; Tanzarella, O.A.; Porceddu, E.; Ciaffi, M. Identification and validation of reference genes for quantitative RT-PCR normalization in wheat. BMC Mol. Biol. 2009, 10, 11. [CrossRef]

48. Li, C.; Lin, H.; Dubcovsky, J. Factorial combinations of protein interactions generate a multiplicity of florigen activation complexes in wheat and barley. Plant J. 2015, 84, 70-82. [CrossRef]

49. Yoo, S.D.; Cho, Y.-H.; Jen, S. Arabidopsis mesophyll protoplasts: A versatile cell system for transient gene expression analysis. Nat. Protoc. 2007, 2, 1565-1572. [CrossRef]

50. Wydro, M.; Kozubek, E.; Lehmann, P. Optimization of transient Agrobacterium-mediated gene expression system in leaves of Nicotiana benthamiana. Acta Biochim. Pol. 2006, 53, 289-298. [CrossRef]

51. Cheng, Y.; Wang, X.; Yao, J.; Voegele, R.T.; Zhang, Y.; Wang, W.; Huang, L.; Kang, Z. Characterization of protein kinase PsSRPKL, a novel pathogenicity factor in the wheat stripe rust fungus. Environ. Microbiol. 2015, 17, 2601-2617. [CrossRef]

52. Holzberg, S.; Brosio, P.; Gross, C.; Pogue, G.P. Barley stripe mosaic virus-induced gene silencing in a monocot plant. Plant J. 2002, 30, 315-327. [CrossRef] [PubMed]

53. McNeal, F.H.; Konzak, C.F.; Smith, E.P.; Tate, W.S.; Russell, T.S. A Uniform System for Recording and Processing. Cereal Research Data; United States Department of Agriculture, Agricultural Research Service: Washington, DC, USA, 1971; pp. 34-121.

54. Liu, J.; Han, L.; Huai, B.; Zheng, P.; Chang, Q.; Guan, T.; Li, D.; Huang, L.; Kang, Z. Down regulation of a wheat alkaline/neutral invertase correlates with reduced host susceptibility to wheat stripe rust caused by Puccinia striiformis. J. Exp. Bot. 2015, 66, 7325. [CrossRef]

55. Del Sal, G.; Manfioletti, G.; Schneider, C. The CTAB-DNA precipitation method: A common mini-scale preparation of template DNA from phagemids, phages or plasmids suitable for sequencing. Biotechniques 1989, 7, 514-520.

56. Wang, C.F.; Huang, L.L.; Buchenauer, H.; Han, Q.M.; Zhang, H.C.; Kang, Z.S. Histochemical studies on the accumulation of reactive oxygen species $\left(\mathrm{O}^{2-}\right.$ and $\left.\mathrm{H}_{2} \mathrm{O}_{2}\right)$ in the incompatible and compatible interaction of wheat-Puccinia striiformis f. sp. tritici. Physiol. Mol. Plant Pathol. 2007, 71, 230-239. [CrossRef]

57. Ayliffe, M.; Devilla, R.; Mago, R.; White, R.; Talbot, M.; Pryor, A.; Leung, H. Nonhost resistance of rice to rust pathogens. Mol. Plant Microbe Interact. 2011, 24, 1143-1155. [CrossRef]

58. Segarra, G.; Jáuregui, O.; Casanova, E.; Trillas, I. Simultaneous quantitative LC-ESI-MS/MS analyses of salicylic acid and jasmonic acid in crude extracts of Cucumis sativus under biotic stress. Phytochemistry 2006, 67, 395-401. [CrossRef]

59. Kumar, A.; Kaur, G.; Goel, P.; Bhati, K.K.; Kaur, M.; Shukla, V.; Pandey, A.K. Genome-wide analysis of oligopeptide transporters and detailed characterization of yellow stripe transporter genes in hexaploid wheat. Funct. Integr. Genom. 2019, 19, 75-90. [CrossRef]

60. Scofield, S.R.; Huang, L.; Brandt, A.S.; Gill, B.S. Development of a virus-induced gene-silencing system for hexaploid wheat and its use in functional analysis of the Lr21-mediated leaf rust resistance pathway. Plant Physiol. 2005, 138, 2165-2173. [CrossRef]

61. Bartley, G.E.; Scolnik, P.A. Plant carotenoids: Pigments for photoprotection, visual attraction, and human health. Plant Cell 1995, 7, 1027-1038. 
62. Curie, C.; Cassin, G.; Couch, D.; Divol, F.; Higuchi, K.; Le Jean, M.; Misson, J.; Schikora, A.; Czernic, P.; Mari, S. Metal movement within the plant: Contribution of nicotianamine and yellow stripe 1-like transporters. Ann. Bot. 2009, 103, 1-11. [CrossRef]

63. Gross, J.; Stein, R.J.; Fett-Neto, A.G.; Fett, J.P. Iron homeostasis related genes in rice. Genet. Mol. Biol. 2003, 26, 477-497. [CrossRef]

64. Koike, S.; Inoue, H.; Mizuno, D.; Takahashi, M.; Nakanishi, H.; Mori, S.; Nishizawa, N.K. OsYSL2 is a rice metal-nicotianamine transporter that is regulated by iron and expressed in the phloem. Plant J. 2004, 39, 415-424. [CrossRef]

65. Yordem, B.K.; Conte, S.S.; Ma, J.F.; Yokosho, K.; Vasques, K.A.; Gopalsamy, S.N.; Walker, E.L. Brachypodium distachyon as a new model system for understanding iron homeostasis in grasses: Phylogenetic and expression analysis of Yellow Stripe-Like (YSL) transporters. Ann. Bot. 2011, 108, 821-833. [CrossRef] [PubMed]

66. Van Loon, L.C.; Rep, M.; Pieterse, C.M. Significance of inducible defense-related proteins in infected plants. Annu. Rev. Phytopathol. 2006, 44, 135-162. [CrossRef] [PubMed]

67. Martin, G.B. Functional analysis of plant disease resistance genes and their downstream effectors. Curr. Opin. Plant Biol. 1999, 2, 273-279. [CrossRef]

68. Coll, N.S.; Epple, P.; Dangl, J.L. Programmed cell death in the plant immune system. Cell Death Differ. 2011, 18, 1247-1256. [CrossRef]

69. Chamnongpol, S.; Willekens, H.; Moeder, W.; Langebartels, C.; Sandermann, H.; Van Montagu, A.; Inze, D.; Van Camp, W. Defense activation and enhanced pathogen tolerance induced by $\mathrm{H}_{2} \mathrm{O}_{2}$ in transgenic tobacco. Proc. Natl. Acad. Sci. USA 1998, 95, 5818-5823. [CrossRef]

70. Yan, S.; Dong, X. Perception of the plant immune signal salicylic acid. Curr. Opin. Plant. Biol. 2014, $20,64-68$. [CrossRef]

71. Serrano, I.; Romero-Puertas, M.C.; Sandalio, L.M.; Olmedilla, A. The role of reactive oxygen species and nitric oxide in programmed cell death associated with self-incompatibility. J. Exp. Bot. 2015, 66, 2869-2876. [CrossRef]

72. Khan, M.I.R.; Asgher, M.; Khan, N.A. Alleviation of salt-induced photosynthesis and growth inhibition by salicylic acid involves glycinebetaine and ethylene in mungbean (Vigna radiata L.). Plant Physiol. Biochem. 2014, 80, 67-74. [CrossRef] [PubMed]

73. Poór, P.; Takács, Z.; Bela, K.; Czékus, Z.; Szalai, G.; Tari, I. Prolonged dark period modulates the oxidative burst and enzymatic antioxidant systems in the leaves of salicylic acid-treated tomato. J. Plant Physiol. 2017, 213, 216-226. [CrossRef] [PubMed]

74. Cao, H.; Glazebrook, J.; Clarke, J.D.; Volko, S.; Dong, X. The Arabidopsis NPR1 gene that controls systemic acquired resistance encodes a novel protein containing ankyrin repeats. Cell 1997, 88, 57-63. [CrossRef]

75. Dong, X. NPR1, all things considered. Curr. Opin. Plant Biol. 2004, 7, 547-552. [CrossRef]

76. Nostadt, R.; Hilbert, M.; Nizam, S.; Rovenich, H.; Wawra, S.; Martin, J.; Küpper, H.; Mijovilovich, A.; Ursinus, A.; Langen, G. A secreted fungal histidine-and alanine-rich protein regulates metal ion homeostasis and oxidative stress. New Phytol. 2020, 227, 1174-1188. [CrossRef]

Publisher's Note: MDPI stays neutral with regard to jurisdictional claims in published maps and institutional affiliations.

(C) 2020 by the authors. Licensee MDPI, Basel, Switzerland. This article is an open access article distributed under the terms and conditions of the Creative Commons Attribution (CC BY) license (http://creativecommons.org/licenses/by/4.0/). 